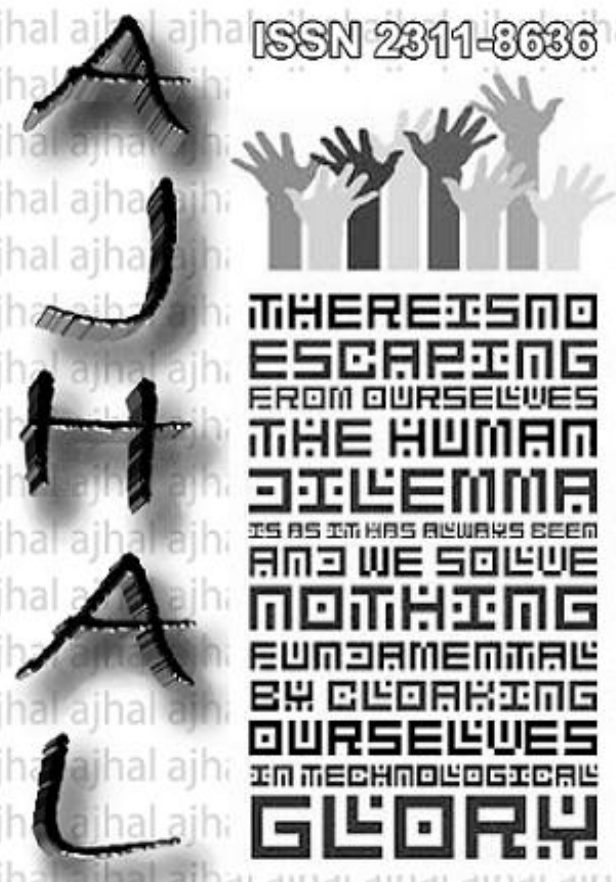

Asian Journal of Humanity, Art and Liteigatul|"

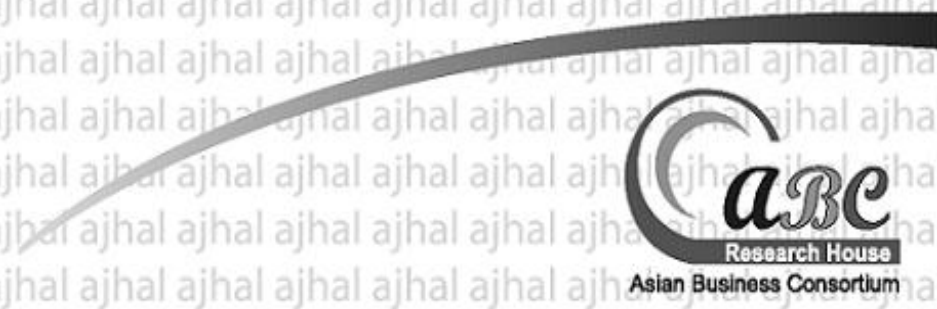




\title{
Roles And Challenges of Secondary School Instructional Leadership for the Achievement of Student Learning: The Case of South Gondar Administrative Zone, Amhara Region, Ethiopia
}

\author{
Misganaw Alene Tsegaye, \& Birara Asnakew Moges
}

Lecturer, Educational Planning and Management, School of Education, University of Gondar, Ethiopia

\begin{abstract}
This study examined the roles and challenges of secondary school instructional leadership for the achievement of student learning in some selected schools in the South Gondar, Ethiopia. The researchers used a descriptive research design of survey type and gathered data through questionnaire and interview. The sample of this study comprises; principals, unit leaders, teachers and students in eight secondary schools in the South Gondar Zone. Thus, one hundred seventy five (175) teachers, seventy five (75) instructional leaders (20 principals, 11 unit leaders \& 44 department heads), two hundred eighty five (285) students and eleven (11) officials at regional and district level were selected. Five research questions guided the study. The data collected were analyzed through the computation of percentages. Findings indicated significant relationships between distributed leadership and school goal achievement; teachersâ $€^{\mathrm{TM}}$ professional development; instructional programme management; effective teaching and learning; and promotion of school climate which include facilitating and understanding of the lesson, create an interesting environment with high class participation. Based on this finding, school heads/authorities should make it mandatory that distributed leadership should be adopted in such a way that everyone in schools is empowered to make his or her job more efficient, meaningful, and effective.
\end{abstract}

Key words: Challenge, Distributed Leadership, Instructional Leadership, Roles

\section{INTRODUCTION}

Principal has a responsibility of providing vision, leadership and direction for the school and so that it is managed and organized to meet its aims and targets MOE (Ministry of Education, 2012).

Educators must prepare students locally to become citizens in a global world. Efforts to improve student achievement can succeed dominantly when there are school leaders who properly practice their instructional leadership roles (Darling-Hammond, 2005). 
However, the quality of education and competencies of school principals, are now at the center of an intense national debate. There are a myriad of factors, which enter this arena including the content taught, the teachers who deliver the curriculum, and the leaders who work with teachers, students, and the community (Cunningham and Paula, 2009).

The evidence is almost uniformly consistent in indicating policy initiatives that focus solely on leadership and management have difficulty in achieving more than a generalized impact on student learning. Rather the job of school principals has been transformed by extraordinary economic, demographic, technological, and global change (Levine, 2005). Though principals play a vital role in setting the direction for successful schools, existing work environment of public secondary school principals is encountered by various impediments.

This study attempts to contribute to the knowledge base by exploring the challenges school principals face so that appropriate strategies to alleviate such challenges should be devised and implemented in Amhara region, Ethiopia.

\section{Statement of the Problem}

This research was necessitated by what the researchers observed during their six years stay in the Public Secondary Schools. It was observed that principals played the most crucial role in ensuring schools' effectiveness and performance. Without the necessary skills, competencies and intrinsic motivations, many school principals are overwhelmed by the enormous task (Hamersley, 2012). In most of developing countries including Ethiopia, principals have hardly any formal managerial and leadership training and most of them are appointed on the basis of their teaching record other than their leadership potentials (Kiumi, Bosire \& Sang, 2009).

Many if not most of these principals in South Gondar Zone, Amhara region often have to work in poorly equipped secondary schools with inadequately trained subordinate staff in the various units of the school. Besides, as far as the researchers used to be part of the system for a couple of years, the environments within which the principals working are found to be full of troubles that are common to a populous region in the country.

Having this in mind therefore, this study investigates the challenges secondary school principals face in carry out their duties and responsibilities; and the perception about their leadership roles in South Gondar Administrative Zone, Amhara Region. Based on these reasons the following research questions were used for the proposed study:

- How do instructional leaders and students rate on principals' leadership behavior in promoting the success of student learning?

- How does the concept of distributed leadership, as perceived by the principals and vice- principals, link to teaching and learning?

- What instructional leaders and students believe are the major challenges confronting secondary school principals of South Gondar Administrative Zone, Amhara Region?

- What instructional leaders and students believe are the causes of these challenges to be?

- How do secondary school principals tackle the major challenges they confront?

\section{Purpose OF THE Study}

The purpose of this study was to examine the challenges secondary school instructional leaders face in carry out their leadership roles in the achievement of student learning in South Gondar Zone, Amhara region. The research also attempted investigating the effect of principals' perceptions that leadership competencies including leadership development experiences have on the school outcomes. 
The sub-aims of the study include:-

i. to explore the challenges secondary school instructional leaders face in carry out their leadership roles in South Gondar Zone, Amhara region.

ii. to investigate the major causes of the challenges facing secondary school instructional leaders in carrying out their leadership roles and determining possible measures that can be taken to overcome these challenges.

iii. to analyze how the distributed leadership relates to a selection of leadership competencies so as to have effective teaching-learning.

iv. to explore the perception of secondary school instructional leaders about their leadership roles.

\section{SigNIFICANCE OF THE STUDY}

The study was conducted to increase knowledge and understanding about the complex nature of the challenges that confront secondary school instructional leaders as they execute their overall roles and responsibilities. The study further examined the leadership competencies that principals, vice-principals, department heads, unit leaders and teachers in South Gondar Administrative Zone believe they would need to meet the challenges they face in carrying out their leadership roles.

This research was expected to present an articulation of the benefit of competencies of distributed or collective leadership to tackle the challenges facing public secondary school instructional leaders in carry out their leadership roles as represented in the literature and understood by principals, vice-principals, department heads, unit leaders and teachers- to the benefit of policy-makers, professional development providers and practitioners in the region. The other most important value of this study was to provide timely documented data and information to others who could be interested in conducting similar studies in this particular area.

\section{SCOPE OF THE STUDY}

The study focused on the challenges facing secondary school instructional leaders and their perceptions about their leadership roles. The study dealt with mixed methods approach in order to collect data using both quantitative and qualitative methods.

\section{LIMITATION OF THE STUDY}

This study was encountered by the following major difficulties such as financial problem, time constraint and baseline research.

\section{Research Design and Methodology}

A descriptive survey was used to depict the existing condition of the secondary school principalship or instructional leadership and eventually determine the factors generating, influence on the achievement of student learning in the South Gondar Zone, Amhara Region.

\section{Sources of Data and Sampling Techniques}

The study population were divided in to strata on the bases of role differentiation i.e., principals, teachers, unit leaders, department heads and students from different grade levels and education officials at Region and Woredas level. 
South Gondar Administrative Zone is one of the ten administrative Zones in Amhara National Regional State of Ethiopia. This administrative zone is made up of ten woredas. According to the Education Statistics Annual Abstract (MOE, 2012) there are 315 public and private secondary schools of Amhara region, out of which 296 (94\%) are administered by the regional government. From these 296 public secondary schools 34 are found in South Gondar Administrative Zone so that they are the study population.

Therefore, source of data for the study was South Gondar Administrative Zone. Five woredas / districts were selected from this administrative zone using random sampling technique. The reasons for the purposeful selection of this administrative zone were first its proximity to the university in order to carry out this research simultaneously with regular activities thereby avoiding inconveniences related to financial and time constraints for the researcher. Hence, Libo-kemkem, Fogera, Debre-Tabor, Lay-Gaint and Simada Woredas were included for the investigation.

Accordingly, one secondary \& one preparatory, two schools from each sample Woreda were selected on the basis of stratified purposive sampling techniques in order to incorporate both first cycle (9-10 grade) and preparatory (11-12 grade) levels. Besides, principals and vice-principals of all selected schools were included using available sampling techniques. On the other hand teachers, unit leaders and department heads were selected using random sampling technique. In identifying the sample student respondents, variables such as gender and grade levels were taken in to account. Therefore, taking these variables in to consideration, student samples were selected on the basis of random sampling technique on the ground that they represent the total population. The heads of Education offices at Regional and Woreda level were selected using availability sampling technique.

Consequently from 8 purposefully selected secondary \& preparatory government schools, a total of 75 instructional leaders (20 principals \& vice principals, 11 unit leaders and 44 department heads), 175 teachers, and 11 officials from the two echelon of the sector were taken. From the rest of the population (students) due to their large size, only 285 students were considered as sample population to overcome the problem of managing huge size of the population. The respondents were determined with the assumption that responses obtained from this number provide sufficient and essential details on the problem under investigation.

\section{Data Collection Tools}

Questionnaires, interview and observations were employed for the generation and collection of data. Questionnaires were utilized for student, teacher and instructional leader respondents to obtain relevant data related to common practical application of principals' and other instructional leadership roles \& challenges. Interviews with education officials, and observations were used to counter check instructional leaders' status of performance so as to evaluate students' achievement and to generate useful data to analyze the variations that may exist as a result of instructional leaders' professional development programs conceptual understanding, practices and challenges in carry out their leadership roles.

\section{Data Analysis and Interpretation}

In analyzing the data gathered, both qualitative and quantitative methods were employed. The quantitative data are analyzed using percentage. The qualitative analyses are mostly employed in narrative forms for the report pertaining to interviews and field observation. 


\section{THE REVIEW OF ReLATEd Literature}

\section{The Concept and Origin of School leadership}

Leadership is one of the most complex human behaviors. Although there is no one single way to view leadership, experts of the field usually define leadership according to their contextual perspective and the facets of the phenomenon of most interest to them.

While sociologists, psychologists, strategists, historians, and business analysts have made significant progress in learning about leadership, there remains no single universally accepted definition for a leader (Yukl, 2002). Besides, Lyne de Ver (2009) highlights that "There is no unanimity as to what leadership means". This leads to describe leadership as many things to many people.

Northouse (2007) defines leadership as "a process whereby an individual influences a group of individuals to achieve a common goal." These definitions suggest several components central to the phenomenon of leadership. Some of them are as follows: (a) Leadership is a process, (b) leadership involves influencing others, (c) leadership happens within the context of a group, (d) leadership involves goal attainment, and (e) these goals are shared by leaders and their followers. If we take one of the components of the definition of leadership for instance, the very act of defining leadership as a process suggests that leadership is not a characteristic or trait with which only a few, certain people are endowed with at birth. Defining leadership as a process means that leadership is a transactional event that happens between leaders and their followers.

Therefore, regardless of different approaches to its definition, leadership is a process whereby individuals influencing a group of individuals to achieve a common goal. Leadership is the relationship in which one person, the leader, influences others to work together willingly on related tasks so that they will strive towards the achievement of group goals (Northouse, 2007). The researcher will not attempt to resolve the controversy over the most appropriate definition of leadership as part of this study; rather the various definitions will be viewed as a source of deferent perspectives, on a complex, multifaceted phenomenon. The reason for this is that in research, the operational definition of leadership will, to a great extent, depend on the purpose of the research (Campbell, 1987). Despite the wide spread views and controversies over the definition of leadership, Halverson (2005) states that it is now more than 20 years since educational leadership was identified as one of the key components of 'good schools'. The report for the Annual Meeting of the National Council of Professors of Educational Administration (2005), also suggested that the most important single factor in the success schools is the quality of the leadership of the head. Fullan (2006:P. 10) also noted that "A highly effective school leader can have a dramatic influence on the overall academic achievement of students". Based on this public demands for more effective schools have placed growing attention on the crucial role of school leaders in promoting successful teaching and learning. Another research as well suggests that effective instructional leadership strongly affects the quality of teaching and student learning (Leithwood, Seashore, Anderson and Wahlstrom, 2004). The indispensable role of educational leaders is emphasized by experts of the field in such a way that educational administration practice is a blending of knowledge, practice, politics, ethics traditions and new visions (Cunningham and Paula, 2009).

Not only this but also the job of school leaders has been transformed by extraordinary economic, demographic, technological, and global change (Levine, 2005). Because it is natural that the school leaders are changed with the responsibility to create a school climate that is sensitive to diverse situations. 


\section{The Role of the Instructional leadership}

The role of the instructional leader has changed considerably since its formal inception in the early 1900s, shifting according to political eras and societal changes (Goodwin, et al., 2003). The school leader's role did not exist in the one-room schoolhouse, as teachers performed all functions. As schools grew in size and bureaucracy increased, the role was officially recognized in the early 1900s as one of manager and coordinator of activities. The nature of the role varied over time depending on social paradigm, politics, and the economy, but it was with the development of stronger, more vocal and active unions in the 1970s that the role of the principal shifted from "that of a colleague of teachers to a representative of the school board" (p. 5), and the years followed with increased centralization and increased bureaucracy (Tyack and Hansot, 1982).

Goodwin et al. (2005) reported that bureaucracy, social forces, collective bargaining, and other reforms eroded the instructional role of the principal and his/her assistants so much so that principals used to consider themselves educators, but now "the problem is much too complicated, the organization much too vast, the ramifications are too great, the partners in the enterprise are too many for [principals] to serve any longer as educators" (p. 5).

Over the past two decades however, as accountability reforms have made their way into schools, there is formidable pressure for the principal to take on less of a managerial role in favour of instructional leader. Having been outside the instructional realm for some time, re-engaging in instruction and, furthermore, in improving the instructional performance of others presents a significant challenge for principals (Hallinger, 2003; Stronge, 1993): so much of a challenge that the shift from principal as manager to principal as instructional leader has not yet been effectively made. Instructional leadership in schools continues to be a challenge today firstly due to its narrow definition cast against the large number of roles of the principalship. Stronge (1993) stated that because the job entails a large component of managerial duties and demands, instructional leadership is difficult to achieve. Some of these demands of the principalship have been created by social forces and others by policy issues (Goodwin et al., 2003), but they have all resulted in "leadership issues including the layering of additional responsibility without corresponding authority, an imbalance between management and leadership despite the expansion of the work week, an increase in ambiguity and complexity, and declining morale and enthusiasm" (p. 8). In addition, the role of the principal is further extended because different factions of society expect different outcomes from schools, calling principals to be responsive to multiple demands (Catano and Stronge, 2007; Cuban, 1984). Secondly, the limited proliferation of instructional leadership may be due to the limited empirical evidence that instructional leadership brings about improved student learning (Cuban, 1984; Hallinger, 2008). From a student perspective, school leadership accounts for only $12-25 \%$ of student learning outcomes (Leithwood, 2012), while external environment and family-related factors can account for as much as $50 \%$ of the effects on student achievement (Leithwood et al., 2010).

\section{Instructional Leadership in the Ethiopian Context}

Education has been established as the leading power to promote the well being of society by promoting economic growth, creating wealth and development. Ethiopia started introducing modern education in the 1940s (Lemlem, 2010). It has remained essential for the country to come out of poverty. And the challenge has been to create educated human capital and skills through developing an education system built and legitimized by the active participation of all the stakeholders who agree to resource and support education development. But several 
studies (Pankhurst, 1999; Tekeste, 2006; World Bank, 2005; Damtew, 2007; Endawke, 2009) have shown that Ethiopia's educational expansion is plagued by the prevalence of poor quality across the education sectors from primary to higher education.

The severe challenges have been faced by educational leaders along with dealing an improvement movement in student achievement through a consistent focus on the enhancement of the teaching/learning process and the transformation of the school into a motivational and child friendly learning environment.

Although there is lack of empirical evidences with regard to the degree of the challenges currently facing school principals at all levels of the system, the deteriorating quality of education reveals the prevalence of the problem. Among the observable problems principals are found to work in a very complex and challenging environment characterized by tensions; conflicts; poor security; alcohol and substance abuse among students and related issues; lack of adequate finance and meager resources, pressure from various stakeholders and the impact of socio-political issues. Onderi and Andrew (2013) reported identical problems that encountered secondary school principals in Kenya that indicate such challenges to global. There is also evidence of lack of qualified and competent teachers. It is emerged that principals or head teachers are not well trained and supported in their roles and responsibilities. These factors not only undermined the quality of education but also the schools' performance in national examinations. Therefore, this descriptive survey is conducted to examine the common challenges facing public secondary school principals of South Gondar in Amhara region of Ethiopian.

\section{Data Organization, PResentation, Analysis and Interpretation}

This part of the study deals with analysis of data. The data for the study consist of primary sources from responses gathered through three sets of questionnaires designed and administered for three groups of respondents (students, teachers and school leaders). Interview was also conducted with regional and woreda officials, in order to obtain a more in-depth picture of the issues arising from the questionnaires.

\section{Description of Sample population}

The Data used in this study were collected from questionnaires administered to the roles and challenges of instructional leaders for the achievement of students learning. Interview was conducted with Regional and Woreda Education Bureau Heads.

\section{Characteristics of Respondents}

Table 1 shows classification of respondents by sex, level of education and in different age categories. As indicated in the table, $84 \%$ of the teachers were males where as females constitute only $13.1 \%$ and $2.85 \%$ did not respond regarding their sex category. Based on the results of the table most teachers that constituted high schools in the target zone are male with the implication of the gender mix appeared to be in favor of males over females. Therefore, schools shall require that utilizing female teachers who have an important professional qualities and whose work may create a significant impact upon the learning of students should be given appropriate emphasis. 
Table I. Characteristics of Teacher Respondents

\begin{tabular}{|c|c|c|c|c|}
\hline \multirow[t]{3}{*}{ No } & \multirow{3}{*}{\multicolumn{2}{|c|}{ Item }} & \multirow{2}{*}{\multicolumn{2}{|c|}{$\begin{array}{l}\text { Respondents } \\
\text { Teachers }\end{array}$}} \\
\hline & & & & \\
\hline & & & No & $\%$ \\
\hline \multirow[t]{5}{*}{1} & \multicolumn{2}{|l|}{ Sex } & & \\
\hline & & Male & 147 & 84. \\
\hline & b) & Female & 23 & 13.14 \\
\hline & c) & Not responded & 5 & 2.86 \\
\hline & \multicolumn{2}{|l|}{ Total } & 175 & 100 \\
\hline \multirow[t]{8}{*}{2} & \multicolumn{2}{|c|}{ Level of education } & & \\
\hline & a) & 12+TTI & 1 & 0.6 \\
\hline & b) & $12+2$ & 4 & 2.3 \\
\hline & c) & $10+3$ & 2 & 1.1 \\
\hline & d) & BA/BSC & 161 & 92 \\
\hline & e) & MA/MSC & 4 & 23 \\
\hline & f) & Not responded & 3 & 1.7 \\
\hline & \multicolumn{2}{|l|}{ Total } & 175 & 100 \\
\hline \multirow[t]{9}{*}{3} & \multicolumn{2}{|l|}{ Age } & & \\
\hline & a) & $20-25$ & 50 & 28.6 \\
\hline & b) & $26-30$ & 58 & 33.1 \\
\hline & c) & $31-35$ & 19 & 10.9 \\
\hline & d) & $36-40$ & 17 & 9.7 \\
\hline & e) & $41-45$ & 14 & 8 \\
\hline & f) & $46-50$ & 11 & 6.3 \\
\hline & \multicolumn{2}{|c|}{ Note responded } & 6 & 3.4 \\
\hline & \multicolumn{2}{|c|}{ Total } & 175 & 100 \\
\hline
\end{tabular}

Regarding educational qualification of the respondents, it is found out that $161(92 \%)$ of them are Bachelor degree holders. It was only 4(2.3 percent) respondents with second degree qualification. From the data given, it is possible to infer that most high schools are staffed with people having the required level of qualification which in turn has a positive effect on the quality of education. To understand the age mix of the respondents in this regard an item is prepared. Accordingly it is depicted that 50(28.6 percent) 58(33.1 percent), 19(10.9 percent), 17 (9.7 percent) 14 (8 percent) of the respondents are between the age ranges 20-25, 26-30, 31-35, $36-40,41-45$ and $46-50$ respectively. What one conclude from this data is that quite a good deal of the respondents 50(28.6 percent) and 58(33.1 percent) are youth with the implication that they are energetic having a positive contribution for the schools if properly utilized.

Table II. Local community mobilization skill

\begin{tabular}{|l|l|l|l|}
\hline 4 & $\begin{array}{l}\text { Where do most of the educational resources } \\
\text { for the school come from? }\end{array}$ & \\
\cline { 2 - 4 } & Gov't budget & 129 & 73.7 \\
\cline { 2 - 4 } & Local community & 25 & 14.7 \\
\cline { 2 - 4 } & Income generating activities & 10 & 5.7 \\
\cline { 2 - 4 } & Others & 2 & 1.1 \\
\cline { 2 - 4 } & Not responded & 9 & 5.1 \\
\cline { 2 - 4 } & Total & 175 & 100 \\
\hline 5 & $\begin{array}{l}\text { How do you see parent-teacher association } \\
\text { in the management of the school? }\end{array}$ & & \\
\hline & a) PTA plays greater role & 34 & 19.4 \\
\hline & b) PTA hasn't significant role & 101 & 57.7 \\
\hline & c) PTA hasn't any role & 30 & 17.1 \\
\hline & d) Not responded & 10 & 5.7 \\
\hline & Total & 175 & 100 \\
\hline
\end{tabular}

Asian Business Consortium | AJHAL 
Educational institutions are characterized by the utilization of a massive amount of resource coming from different sources. When replying to the item that stresses on the sources of educational resource quite a significant number of the respondents underlined that the lion's share of the school finance comes from the public budget. This shows that the leadership role of instructional leaders is challenged due to the scarcity of resources for the reason that the resource that comes from the government is very limited as there is a number of competing demands that urge the government for careful consideration.

Parent-teacher Associations (PTA) have a strong administrative role in backing up the leadership task of instructional leaders. This is best explained in the guidelines of both the MOE and REB. And identifying the degree to which this important administrative body i.e. PTA playing its presumed role is an issue raised in this research. As a result, it is observed in the above table that PTA's involvement in the instructional leadership is not as good as it has been expected. This entails that instructional leaders are in a difficult situation in mobilizing the schools as well as the outside community which in turn may affect the quality of education offered at schools.

\section{Principals Coordinating Skill}

\begin{tabular}{|c|c|c|c|}
\hline \multirow[t]{3}{*}{ No } & \multirow[t]{3}{*}{ Item } & \multirow{2}{*}{\multicolumn{2}{|c|}{$\begin{array}{l}\text { Respondents } \\
\text { Teachers }\end{array}$}} \\
\hline & & & \\
\hline & & No & $\%$ \\
\hline \multirow[t]{6}{*}{6} & The extent to which the principal encourage team work & & \\
\hline & a) High & 31 & 17.7 \\
\hline & b) Medium & 91 & 52 \\
\hline & c) Low & 49 & 28 \\
\hline & d) Not responded & 4 & 2.3 \\
\hline & Total & 175 & 100 \\
\hline \multirow[t]{6}{*}{7} & $\begin{array}{l}\text { How do you rate the skill of the principal to coordinate } \\
\text { different departments? }\end{array}$ & & \\
\hline & a) High & 24 & 13.7 \\
\hline & b) Medium & 95 & 54.3 \\
\hline & c) Low & 47 & 26.5 \\
\hline & d) Don't responded & 9 & 5.1 \\
\hline & Total & 175 & 100 \\
\hline
\end{tabular}

Instructional leadership skills such as team building and the skill of coordinating different stakeholders in order to get various supports have important role in determining the effectiveness of leadership for the attainment of its ultimate objective. To portray information in this respect focusing on assessing realities related to team building skills and coordinating skills are designed. Consequently those teacher respondents who constitute 142 (81 percent) confirmed that principals have "medium and Low" team building skills and of the other group respondents comprising 24 (13.7 percent) declared that the existence of high level of coordinating skill. This therefore leads to the conclusion that instructional leaders have the problem of understanding the potential gains that come from working in team and coordinating the different departments towards the same end. 
Table IV. Empowering Others to Make Significant Decisions:

\begin{tabular}{|c|c|c|c|}
\hline \multirow[t]{3}{*}{ No } & \multirow[t]{3}{*}{ Item } & \multirow{2}{*}{\multicolumn{2}{|c|}{$\begin{array}{l}\text { Respondents } \\
\text { Teachers }\end{array}$}} \\
\hline & & & \\
\hline & & No & $\%$ \\
\hline \multirow[t]{6}{*}{10} & The kind of leadership approach the principal follows: & & \\
\hline & a) Autocratic & 23 & 13.1 \\
\hline & b) Democratic & 99 & 56.6 \\
\hline & c) Laissez-fair & 37 & 21.1 \\
\hline & d) Not responded & 16 & 9.2 \\
\hline & Total & 175 & 100 \\
\hline \multirow[t]{6}{*}{11} & How often does the principal empower teachers? & & \\
\hline & a) Always & 46 & 26.3 \\
\hline & b) Sometimes & 104 & 60.5 \\
\hline & c) Not at all & 22 & 12.8 \\
\hline & d) Not responded & 3 & 1.7 \\
\hline & Total & 175 & 100 \\
\hline \multirow[t]{6}{*}{12} & $\begin{array}{l}\text { The extent to which teachers are encouraged in group } \\
\text { decision making: }\end{array}$ & & \\
\hline & a) High & 32 & 18.3 \\
\hline & b) $\quad$ Medium & 95 & 54.3 \\
\hline & c) Low & 45 & 25.7 \\
\hline & d) Not responded & 3 & 1.7 \\
\hline & 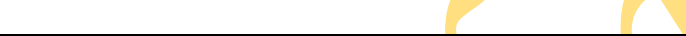 & 175 & 100 \\
\hline
\end{tabular}

Items in the above table are designed to reveal the kind of leadership approach educational managers adhere to. Accordingly, it was depicted that 99(56.6 percent of them exercise democratic style and 37(21.1 percent of them are found to maintain the laissez fair type. Asked whether or not educational leaders empower their subordinates, out of the same group of respondents 104(60.5 percent) responded the reverse of democratic leadership style (they do it sometimes). Another item meant for examining the extent of group decision making was introduced. As a result 95(54.3 percent) and 45(25.7 percent) witnessed by responding "medium" and "low" respectively when explaining the existence of group decision making for matters that affect the school system.

It is observed from the responses of teacher respondents that democratic leadership is mixed up with the absence of coercive measures. The inexistence of democratic leadership is mixed up with the presence of coercive measures. The inexistence of democratic leadership, however, is portrayed from other responses when the greatest proportion of the respondents confirm empowerment and group decision making are poorly practiced at schools.

Table V. Developing and Implementing Strategic and School-Improvement Plans:

\begin{tabular}{|l|l|l|l|}
\hline \multirow{2}{*}{ No } & Item & \multicolumn{2}{l|}{ Respondents } \\
\cline { 3 - 4 } & & \multicolumn{2}{|l|}{ Teachers } \\
\cline { 3 - 4 } & \multicolumn{1}{|l|}{ No } & $\%$ \\
\hline 13 & Does the school have strategic plan? & & \\
\cline { 2 - 4 } & a) Yes & 149 & 88.1 \\
\cline { 2 - 4 } & b) No & 20 & 11.4 \\
\cline { 2 - 5 } & c) Not responded & 6 & 3.4 \\
\cline { 2 - 5 } & Total & & \\
\hline 14 & $\begin{array}{l}\text { The degree to which school activities are carried by } \\
\text { strictly relying on the strategic plan: }\end{array}$ & & 100 \\
\hline
\end{tabular}




\begin{tabular}{|c|c|c|c|}
\hline & a) High & 36 & 20.6 \\
\hline & b) Medium & 107 & 61.1 \\
\hline & Never matches with the strategic plan & 25 & 14.3 \\
\hline & d) Not answered & 7 & 4 \\
\hline & Total & 175 & 100 \\
\hline \multirow[t]{6}{*}{15} & $\begin{array}{l}\text { If your response for item number" } 14 \text { is " } \mathrm{A}^{\prime \prime} \text { or " } \mathrm{B} \text { ", the } \\
\text { degree to which plan is revised to meet current situations: }\end{array}$ & & \\
\hline & a) High & 37 & 21.1 \\
\hline & b) Medium & 69 & 39.4 \\
\hline & c) Low & 29 & 16.6 \\
\hline & d) Not responded & 40 & 22.9 \\
\hline & Total & 175 & 100 \\
\hline
\end{tabular}

An item to see whether or not instructional leaders guide their activities with proper strategic plan is introduced. While responding to this item 149 (88.1 percent) of them confirmed the existence of strategic plan in the schools. This shows that most schools are accustomed in preparing strategic plans. Nevertheless, the preparation of strategic plans alone is not an end in itself. It has to be implemented in line with the scheduled time with the allocation of the resources needed for realizing the objectives set. To investigate whether or not school activities are carried out in line with the strategic plans, an item is introduced and when responding to this item only 30 (20.6 percent) out of 175 respondents mentioned about the existence of high degree of reliance on strategic plans. If school activities go-off the strategic plans, there has to be a mechanism for adjusting them to current situations through periodic revision. And an item to cheek the existence such mechanisms in the implementation of strategic plans is designed. Surprisingly enough 69 (39.4 percent) said medium 29(16.6 percent) "Low" and quite a good deal of the items i.e. 40(23.9 percent) are not responded implying that the respondents don't have the experience of plan revision with the instructional leaders.

A glimpse at the data presented above leads us to the conclusion that schools have the experience of preparing strategic plans but not used it as it is required to be so that whose effect for the development of the teaching and learning process is very much limited. This is because instructional leaders are not in a position to maximize the benefit to be obtained from the implementation of the strategic plans by consistent revision for addressing current resource environment of schools.

Table VI. Principals' Role in Curriculum Revision and Implementation

\begin{tabular}{|c|c|c|c|}
\hline \multirow[t]{3}{*}{ No } & \multirow[t]{3}{*}{ Item } & \multirow{2}{*}{\multicolumn{2}{|c|}{ Respondents }} \\
\hline & & & \\
\hline & & No & $\%$ \\
\hline \multirow[t]{6}{*}{1} & $\begin{array}{l}\text { The extent to which teachers are encouraged to involve } \\
\text { in evaluating the content of the curriculum: }\end{array}$ & & \\
\hline & a) Frequently & 58 & 32 \\
\hline & b) Rarely & 77 & 44 \\
\hline & c) Not at all & 30 & 17.1 \\
\hline & d) Not responded & 12 & 6.9 \\
\hline & Total & 175 & 100 \\
\hline \multirow[t]{5}{*}{2} & Is there a well organized pedagogical center in the school? & & \\
\hline & a) Yes & 58 & 33.1 \\
\hline & b) No & 110 & 62.9 \\
\hline & c) Not responded & 7 & 4 \\
\hline & Total & 175 & 100 \\
\hline
\end{tabular}


Asian Journal of Humanity, Art and Literature, Volume 1, No 1 (2014)

\begin{tabular}{|c|c|c|c|}
\hline \multirow[t]{5}{*}{3} & $\begin{array}{l}\text { The extent to which teachers are encouraged to } \\
\text { prepare supplementary instructional materials: }\end{array}$ & & \\
\hline & a) High & 24 & 13.7 \\
\hline & b) Medium & 90 & 51.4 \\
\hline & c) Low & 54 & 30.9 \\
\hline & d) Not responded & 7 & 4.00 \\
\hline & Total & 175 & 100 \\
\hline \multirow[t]{5}{*}{4} & Are teachers given training on Action research? & & \\
\hline & a) Yes & 69 & 39.4 \\
\hline & b) No & 102 & 58.3 \\
\hline & c) Not responded & 4 & 2.3 \\
\hline & Total & 175 & 100 \\
\hline \multirow[t]{5}{*}{5} & Are teachers encouraged to conduct Action research? & & \\
\hline & a) Yes & 93 & 53.1 \\
\hline & b) No & 73 & 41.7 \\
\hline & c) Not responded & 9 & 5.1 \\
\hline & Total & 175 & 100 \\
\hline
\end{tabular}

Schools are not mere consumers of curriculum prepared by experts apart from their premises. They have to make their curriculum more relevant to local situations through continuous evaluation. An item in this regard to assess if instructional leaders at school level encourage teachers to involve in the evaluation of curricula is prepared. Hence, while 77 (44 percent) of the respondents proved that teacher are rarely encouraged to evaluate curricula materials 30 (17.1 percent) expressed their opposing views. Similarly, to examine the encouragement instructional leaders give to teacher to prepare supplementary teaching materials, the response given for an item prepared in this respect revealed the existence of poor encouragement as can be seen in table VI above. Together with the practices of curricula materials evaluation and supplementary materials preparation, instructional leaders should make sure the existence of well organized pedagogical centers, and an item meant for assessing this situation depicted from the greatest proportion i.e 110 (62.9 percent) of the respondents that pedagogical centers are poorly equipped. This reality is attested in another item when quite a significant number of respondents admitted the insufficient nature of the financial resource allocated to pedagogical centers.

What can be generalized from the data presented is, therefore, that some vital components for effective implementation of curricula are not given the desired attention by instructional leaders making students dependent only on materials prepared by curricular experts who have very little knowledge about the needs and interests of students.

It is frequently stated that schools operate amidst a number of educational problems. If these problems are not immediately intervened, they can cause a huge damage on the performance of schools thereby restraining the realization of educational objectives. Action research in this respect is an important instrument for assessing problems that schools encounter, and giving timely response for them. To examine prevailing situation in relation to the training opportunities teachers are given on action research to develop their knowledge in this regard, an item is designed. While responding to this item the over whelming majority i.e 102(58.3 percent) mentioned as if they don't have the exposure on them. Another item to see whether or not teachers are encouraged to conduct action research by instructional leaders is treated. As a result while 93 (53.1 percent) explained their agreement, 73 (41.7 percent) confirmed their disagreement. 
As can be seen from the majority of the respondents, the culture in schools to solve their problems through action research is minimal for the reason that attempts that instructional leaders make to organize training for teachers on action research is very much restricted. This by itself entails that trends in schools to identify and solve problems that appear in their day to day interaction with the environment are not as promising as they are expected to be.

Table VII: Instructional Program Management

\begin{tabular}{|c|c|c|c|}
\hline \multirow[t]{3}{*}{ No } & \multirow[t]{3}{*}{ Item } & \multirow{2}{*}{\multicolumn{2}{|c|}{$\begin{array}{l}\text { Respondents } \\
\text { Teachers }\end{array}$}} \\
\hline & & & \\
\hline & & No & $\%$ \\
\hline \multirow[t]{5}{*}{1} & $\begin{array}{l}\text { Organizing experience sharing mechanisms amongst } \\
\text { teachers }\end{array}$ & & \\
\hline & a) Top priority & 40 & 22.9 \\
\hline & b) Less priority & 111 & 63.4 \\
\hline & c) Not responded & 24 & 13.7 \\
\hline & Total & 175 & 100 \\
\hline \multirow[t]{5}{*}{2} & $\begin{array}{l}\text { Searching different ways for resourcing the implementation } \\
\text { of the school plans. }\end{array}$ & & \\
\hline & a) Top Priority & 65 & 37.1 \\
\hline & b) Less priority & 87 & 49.1 \\
\hline & c) Not responded & 23 & 13.1 \\
\hline & Total & 175 & 100 \\
\hline \multirow[t]{5}{*}{3} & Coordinating school flag ceremony every day & & \\
\hline & a) Top priority & 111 & 63.4 \\
\hline & b) Less priority & 40 & 22.9 \\
\hline & 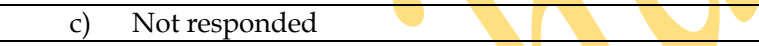 & 24 & 13.7 \\
\hline & Total & 175 & 100 \\
\hline \multirow[t]{5}{*}{4} & $\begin{array}{l}\text { Sponsoring and involving in ordinary meeting within and } \\
\text { without the school }\end{array}$ & & \\
\hline & a) Top priority & 107 & 61.1 \\
\hline & b) Less priority & 45 & 25.7 \\
\hline & c) Not-responded & 23 & 13.1 \\
\hline & Total & 175 & 100 \\
\hline \multirow[t]{5}{*}{5} & Evaluating and following up TDP implementation plans. & & \\
\hline & a) Top priority & 79 & 45.1 \\
\hline & b) Less priority & 71 & 40.6 \\
\hline & c) Not responded & 25 & 14.3 \\
\hline & Total & 175 & 100 \\
\hline
\end{tabular}

Depending on the contribution they have for bringing about quality education, school activities that are carried out by instructional leaders can be categorized as developmental and non-developmental ones. As much as possible instructional leaders should give the greatest proportion of their time, resource and energy to work on those tasks that improve students' learning behavior. To examine the extent to which instructional leaders dedicate a substantial amount of their time on developmental activities a number of tasks having the feature of developmental and non-developmental are designed and administered to the respondents. Respondents are requested to respond to those school activities by saying top priority and less priority.

Accordingly form the different activities listed out those tasks that are designated as top priority are the involvement of principals in coordinating school parade, frequent 
involvement in ordinary meetings sponsored by the school and external institutions and follow up the effective implementation of continuous assessment. And from those activities performed at schools the ones that are designated as less priority by the greatest share of the respondents are organizing experience sharing programs amongst teachers, searching different mechanisms for resourcing the implementation of school plans and evaluating and follow up of teachers' development plans (TDP).

A quick glance at the data presented above exhibits those school tasks that are given top priority efforts. Such activities as involvement in the effective implementation of continuous assessment and follow up of TDP, the rest are non-developmental tasks. They are tasks that should not take the greatest proportion of instructional leaders' energy and time. Whatever importance instructional leaders attach to these tasks, their benefit to improve the quality of education offered at schools is very much inconsiderable.

Conversely, if we examine those activities that are said to have received lesser attention are task that must have been responded otherwise. In effect, organization of experience sharing mechanisms between and among teachers and searching different mechanisms to resource the implementation of school plans are fundamentally developmental tasks. If properly managed, they have an enormous power to push the school to a better state that contributes toward the improvement of the teaching-learning process for the consequent improvement of the students learning outcomes.

Table VIII. Provision of Required Inputs for Learning

\begin{tabular}{|c|c|c|c|}
\hline \multirow[t]{3}{*}{ No } & \multirow[t]{3}{*}{ Item } & \multicolumn{2}{|c|}{ Respondents } \\
\hline & & \multicolumn{2}{|c|}{ Students } \\
\hline & & No & $\%$ \\
\hline \multirow[t]{5}{*}{ 1s } & The subject that has greater scarcity of teachers: & & \\
\hline & a) Social Sciences & 78 & 27.4 \\
\hline & b) Natural Sciences & 174 & 61 \\
\hline & c) Not responded & 33 & 11.6 \\
\hline & Total & 285 & 100 \\
\hline \multirow[t]{5}{*}{2} & $\begin{array}{l}\text { Are all students made to get textbooks of all subjects } \\
\text { on individual basis? }\end{array}$ & & \\
\hline & a) Yes & 111 & 39 \\
\hline & b) No & 172 & 60.3 \\
\hline & c) Not responded & 2 & 0.7 \\
\hline & Total & 285 & 100 \\
\hline
\end{tabular}

Item were designed with the view of examining whether qualified teachers for each course in sufficient quality are assigned and if sufficient books are provided for each student. In responding to the situation related to the availability of students' textbooks from the table presented above, most respondents proved that all text books are not given to students on individual basis. Accordingly, quite an overwhelming majority of the respondents ascertained that the subjects that suffer from the dearth of teachers are natural science streams.

As can be witnessed from the majority of the respondents, instructional leaders face greater challenges in the assignment of teachers specializing in the natural sciences and are also entertaining problems regarding the scarcity of students' textbooks. This may entail that assignment of natural science teachers should be prioritized and the distribution of textbooks requires the devising of a mechanism that give students the opportunity for accessing them at least for doing their homework's and seat works. 
Table IX: Promotions of Students' Learning environment.

\begin{tabular}{|c|c|c|c|}
\hline \multirow[t]{3}{*}{ No } & \multirow[t]{3}{*}{ Item } & \multirow{2}{*}{\multicolumn{2}{|c|}{$\begin{array}{l}\text { Respondents } \\
\text { Students }\end{array}$}} \\
\hline & & & \\
\hline & & No & $\%$ \\
\hline \multirow[t]{5}{*}{1} & Is there a culture of rewarding better achieving student? & & \\
\hline & a) Yes & 161 & 56.5 \\
\hline & No & 130 & 45.6 \\
\hline & Not responded & 4 & \\
\hline & Total & 285 & 100 \\
\hline \multirow[t]{5}{*}{2} & $\begin{array}{l}\text { If your response for item " } 1 \text { " is yes which groups of students } \\
\text { are rewarded? }\end{array}$ & & \\
\hline & a) $\quad$ Ranking students & 268 & 94.0 \\
\hline & $\begin{array}{l}\text { b) Student that show significant change in their } \\
\text { academic performance from time to time }\end{array}$ & 13 & 4.56 \\
\hline & Not responded & 4 & 1.4 \\
\hline & Total & 285 & 100 \\
\hline \multirow[t]{6}{*}{3} & $\begin{array}{l}\text { If your response is "Yes" for item no } 1 \text { when are rewards for } \\
\text { better academic performance administered }\end{array}$ & & \\
\hline & a) At the end of the $1^{\text {st }}$ semester & 27 & 9.5 \\
\hline & b) At the end of the $2^{\text {nd }}$ semester & 249 & 87.4 \\
\hline & c) Explain if any & - & \\
\hline & d) Not responded & 9 & 3.1 \\
\hline & Total & 285 & 100 \\
\hline
\end{tabular}

Rewarding academically outstanding students has the power of maximizing the efforts of the best achievers and bringing new ones to the system. Unraveling the concern of instructional leaders show to create an environment that rewards best achievers was emphasized in the study and quite a reasonable number of student respondents witnessed as if efforts made in this respect are in a better state. Asked, in another item whether schools give reward to students at the right time and the nature of these students rewarded, most respondents explained that end of the second semester is the time rewards are administered and the students that are considered for the reward are high ranking students.

It is, therefore sound to infer from the data exhibited in the above table that students' rewarding practices have restricted the motivating effect of students' performance. This is because rewarding is done after long period of performance outcomes and only high ranking students are targeted. If rewards are to bring about the desired behavior on the part of students, the time of administration shouldn't be on semester basis and those students who demonstrated significant improvement in their performance have to be part of the reward system even though they do not get rank in their groups.

\section{Table X: Students' Academic Support and Parental Engagement}

\begin{tabular}{|c|c|c|c|}
\hline \multirow[t]{3}{*}{ No } & \multirow[t]{3}{*}{ Item } & \multicolumn{2}{|c|}{ Respondents } \\
\hline & & \multicolumn{2}{|c|}{ Students } \\
\hline & & No & $\%$ \\
\hline 1 & $\begin{array}{l}\text { Has the school Leadership set system to ensure sustainable } \\
\text { academic support for students with special needs? }\end{array}$ & & \\
\hline & a) Yes & 225 & 79 \\
\hline & b) No & 6 & 2 \\
\hline & c) Low & 54 & 19 \\
\hline & d) Not responded & 0 & 00 \\
\hline & Total & 285 & 100 \\
\hline 2 & $\begin{array}{l}\text { If your response for the item above is "yes" the degree of } \\
\text { interest of students to attend academic support programs is? }\end{array}$ & & \\
\hline
\end{tabular}

Asian Business Consortium |AJHAL 
Asian Journal of Humanity, Art and Literature, Volume 1, No 1 (2014)

\begin{tabular}{|l|l|l|l|}
\hline & a) High & 64 & 22.5 \\
\hline & b) Medium & 73 & 25.6 \\
\hline & c) Low & 145 & 50.9 \\
\hline & d) Not responded & 3 & 1.00 \\
\hline 3 & Total & 285 & 100 \\
\hline & $\begin{array}{l}\text { If the response you gave for item no '1' is "yes" what is the } \\
\text { interest of teachers to support such programs? }\end{array}$ & \\
\hline & a) High & 46 & 16.4 \\
\hline & b) Medium & 18.5 \\
\hline & c) Low & 53 & 63.8 \\
\hline & d) Not resounded & 182 & 0,8 \\
\hline & Total & 4 & $100 \%$ \\
\hline & $\begin{array}{l}\text { When does the school management invite students parents' } \\
\text { to school? }\end{array}$ & 285 & \\
\hline & a) When students show behavior problems & 42 & 14.7 \\
\hline & b) When students show misbehaviour & 241 & 84.6 \\
\hline & c) Not responded & 2 & 0.7 \\
\hline
\end{tabular}

To examine the extent to which instructional leaders value the importance of setting extralearning hours for those slow and medium learners to bridge down the learning gaps, an item was introduced to depict current state in this regard. While responding to this item quite a greater proportion of the respondents disclosed the existence of such mechanisms as shown in the table above. Likewise to observe prevailing situations as to whether or not separate programs are designed to intervene in the learning difficulties of poorly achieving students an item was treated. Consequently, as portrayed in the above table a good deal of the respondents affirmed the existence of such intervention strategies. However, the existence of such programs alone cannot be effective unless it is fully accepted by the students and teachers. And to see the interest of students and teachers for such an extra-hour obligation, quite a good number of respondents emphasized that both teachers and students have poor appetite for extra-time helps given to students.

What can be inferred from the responses given by the majority of the respondents is that this kind of programs that have not received recognition both by teachers and students do not serve their purpose. The reason for not getting acceptance by both parties may be instructional leaders' failure to design a suitable schedule that meets current interests of teachers and students.

Students' parents play an irreplaceable role in determining the academic performance of their children. Instructional leaders for this reason have to work in close collaboration with student parents irrespective of the achievement level of the students. An item with the purpose of examining the cause for instructional leaders to invite students' parents at schools is designed as can be seen in the table above. Hence, an overwhelming majority of the respondents admitted that parents are invited to schools when their children manifest behavior problems.

What one can deduce from the data presented above is that instructional leadership has neglected the role of parents in improving the academic achievements of their children. The reason for the instructional leaders to disregard such vital role of parents is that the reluctant behavior parents show when invited to come to school to discuss on matters related to the measures that parents need to take to harness problems that cause poor learning of their children. 
Table XI : Providing instructional guidance:

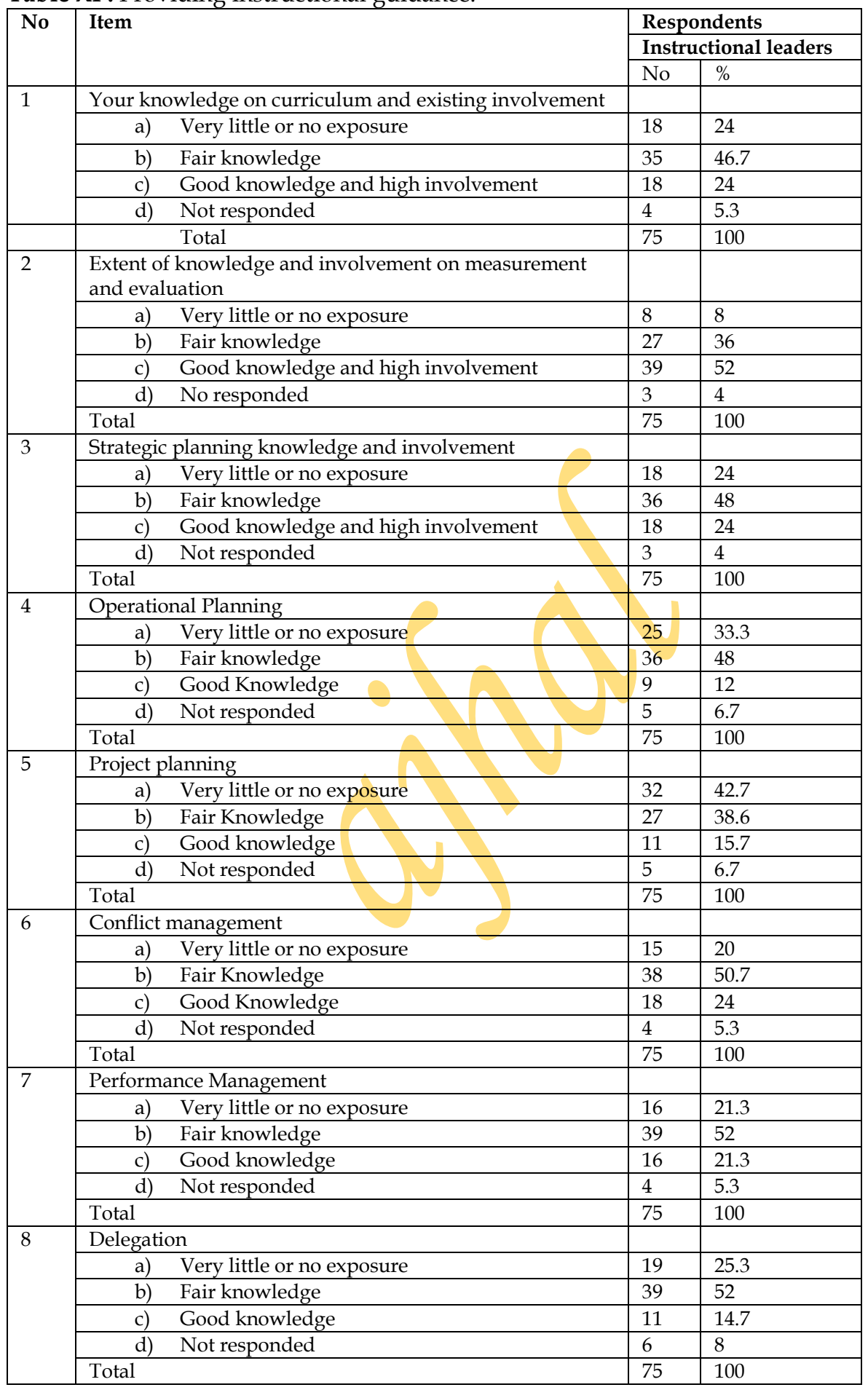


Asian Journal of Humanity, Art and Literature, Volume 1, No 1 (2014)

\begin{tabular}{|c|c|c|c|}
\hline \multirow[t]{6}{*}{9} & Instructional planning & & \\
\hline & a) Very little or no exposure & 13 & 17.3 \\
\hline & Fair Knowledge & 26 & 34.7 \\
\hline & c) Good knowledge & 31 & 41.3 \\
\hline & d) Not responded & 5 & 6.7 \\
\hline & Total & 75 & 100 \\
\hline \multirow[t]{6}{*}{10} & Classroom management & & \\
\hline & a) Very little or no exposure & 7 & 9.3 \\
\hline & b) $\quad$ Fair knowledge & 10 & 13.3 \\
\hline & c) Good Knowledge & 51 & 68 \\
\hline & Not responded & 7 & 9.3 \\
\hline & Total & 75 & 100 \\
\hline \multirow[t]{6}{*}{11} & Action research & & \\
\hline & a) Very little or no exposure & 25 & 33.3 \\
\hline & Fair knowledge & 29 & 38 \\
\hline & Good knowledge & 18 & 24 \\
\hline & Not responded & 3 & 4 \\
\hline & Total & 75 & 100 \\
\hline \multirow[t]{6}{*}{12} & Report Writing & & \\
\hline & a) Very little or no exposure & 14 & 18.7 \\
\hline & b) Fair knowledge & 28 & 37.3 \\
\hline & c) Good Knowledge & 30 & 40 \\
\hline & d) Not knowledge & 3 & 4 \\
\hline & Total & 75 & 100 \\
\hline \multirow[t]{6}{*}{13} & Educational supervision & + & \\
\hline & a) Very little or no exposure & 9 & 12 \\
\hline & b) Fair knowledge & 28 & 37.3 \\
\hline & c) Good knowledge & 35 & 46.7 \\
\hline & d) Not respected & 3 & 4 \\
\hline & Total & 75 & 100 \\
\hline \multirow[t]{6}{*}{14} & \multicolumn{2}{|c|}{ Monitoring and evaluation } & \\
\hline & a) Very little or no exposure & 8 & 10.7 \\
\hline & b) Fair Knowledge & 36 & 48 \\
\hline & c) Good knowledge & 28 & 37.3 \\
\hline & d) Not respected & 3 & 4 \\
\hline & Total & 75 & 100 \\
\hline \multirow[t]{6}{*}{15} & Decision making & & \\
\hline & a) Very little or no exposure & 13 & 18.3 \\
\hline & b) Fair knowledge & 22 & 31 \\
\hline & c) Good knowledge & 36 & 50.7 \\
\hline & d) Not responded & 4 & 5.3 \\
\hline & Total & 75 & 100 \\
\hline
\end{tabular}

The realization of instructional objectives requires instructional leaders to be equipped with a multiplicity of leadership skills. Instructional leadership is not a mere profession that everybody practices without having the appropriate training in areas related to educational management. To this effect with an attitude of examining the extent to which instructional leaders at schools have possessed the skills needed for overcoming their responsibilities a range of managerial functions were listed against which they are required to decide on the level of knowledge and skill they have in them. The result depicted from the above table is that instructional leader in almost all the managerial functions listed proved that they have either very little or no exposure or have fair knowledge in them. This has the implication that they have a deficit in knowledge and 
skill in relation to the basic managerial functions. A possible inference from the data given in the table is that instructional leaders after taking over the position from the rank of teaching are not given the opportunity to get refreshment trainings in the areas of educational management. This implies that these leaders solely rely on the experience they developed when they were serving in the teaching position.

Moreover, in the key staff (teachers, unit leaders, department heads, principals and viceprincipals) survey open-ended questions, asked key staff to select up to five items that they felt were the greatest challenges facing secondary school principal in their school under the leadership of the current position. The responses covered a wide range of areas more or less similar to the close ended items including pupil outcomes, support for pupils, engagement of parents and the community, teaching and learning, staff morale and expectations, collaboration with others and resources mobilization were found to be significant challenges. Besides, heads of education offices at regional and woreda / district level were provided with different questions during their interview with the researcher regarding principals' leadership competencies and the types of continuous development programmes provided for principals. All most all of the respondents reported that the regional education bureau has prepared continuous professional programme so that each principals are participating in order to build their leadership skills, knowledge and attitudes.

Many educational leaders including principals, however, do not yet have the required capacity to exercise their responsibilities effectively (MOE, 2012). School functioning also needs further improvement, in particular concerning school leadership. Irrelevant and uncoordinated training courses have not succeeded in overcoming these challenges: training did not translate systematically into improved work practices. Under ESDP IV, more comprehensive capacity development programs will be developed, aiming at improving the functioning of offices at all levels, of cluster resource centers and of schools, not only the skills of individuals. This will include a greater focus on leadership training. Therefore, officials at regional and woreda level provided unrealistic information that automatically contradicts the existing situation confirmed in the ESDP IV document of Ministry of Education (2012) and the information gathered from key respondents of the survey. This is to mean that concerning leadership competencies, participants ranked from low to midium levels and viewpoints, such as abilities of predicting, arousing, decisionmaking, organizing, implementing, collaborating, communicating, studying, team-spirit, affinity, perseverance, passion, devotion, and charm etc. But participants didn't logically and systematically address leadership competencies by sorting them into three categories - skills, knowledge and attitudes.

\section{Conclusions}

The study was conducted to investigate the challenges secondary school instructional leaders face in carry out their leadership roles in the achievement of student learning in South Gondar Zone, Amhara region. The research also attempted investigating the effect of principals' perceptions that leadership competencies including leadership development experiences have on the school outcomes.

Findings indicated that principal ship positions in most schools of South Gondar Zone are filled with experts drawn from the rank of teaching through competition without the necessary leadership competencies. Nevertheless from the responses of woreda and Regional Education Bureau officials it is disclosed that the interest of teachers to claim for principalship positions is greatly reduced. It is therefore likely to conclude that the possibility of getting motivated and 
competent school heads is to a significant degree questioned as a result of a small number of applicants who voluntarily allow joining the position.

At the heart of the success in leading an organization is the possession of knowledge and skills in managerial spheres. However, the response from the instructional leaders revealed that the knowledge and skill they have in relation to different managerial functions isn't in a sufficient standard. On the basis of these premises it is possible to conclude that efficiency and effectiveness of schools is greatly challenged as a result of poor coordination of instructional leaders emanating from the poor exposure they have in the area of leadership competencies.

As the name implies instructional leadership is the practicing of leadership power to create a fertile school environment for the implementation and development of curricula. The role of instructional leaders to this effect is establishing a school setting that instigates teachers to gear the curricula towards the unique needs of student for making learning meaningful and easy. However, the situation at schools seems to be loose in ensuring the participation of teachers in the harmonization of the curricula with the needs of students. The data shows that the involvement of teacher in the evaluation of the curriculum and the carrying out of action research isn't encouraging. Teachers aren't helped to develop their skills in action research through the provision of training. On the basis of these premises it is possible to conclude that instructional leaders are tightly focused merely on the implementation curricula giving very little attention to the component with immense value for real learning to happen.

The current Ethiopia Education policy is to staff school headship positions with professionals trained in the area of educational leadership. The scarcity of experts trained in this area has made it mandatory to select and appoint school principals from amongst teachers. As a result quite a reasonable degree of school principalship positions are held by teachers with very little knowledge in leadership. This is apparent in the responses solicited from the different respondents. What is clear from this situation is that official except for ensuring the existence of principals in each school aren't much worried about the provision of training in the area of management for those position incumbents. It is therefore possible to conclude that officials are still with the conviction that school headship positions are able to be handled by teachers who don't receive training in educational management.

Only those schools that respond to current societal demands can remain viable in this dynamic world. Such responsiveness can be effectuated if schools attempt to control the increasing volatile situation through the devising of long term thinking and planning. The problem with schools however isn't failure to prepare strategic plans but the situation on which these plans are prepared and implemented. Though schools have their own strategic plans, due to the scarcity of resources, the activities they carryout rarely go in line with the plans. On the other hand, it is found out that instructional leaders spend most of their time engaging in the daily routines. From this situation one is safe to conclude that the causes for instructional leaders not to focus on developmental tasks, is the difficulty of implementing their strategic plans.

\section{RECOMMENDATIONS}

Through above multiple of questions, principals of south Gondar administrative zone have presented their perceptions, opinions, and interpretations regarding the role of principal and leadership development. A relatively concrete picture of a principal's role in a South Gondar Zone's in particular and in the region's schools in general can be envisaged. From this picture, and a deeper understanding about the role of a principal in this region, some suggestions and comments from the researchers can be presented. 
1 Regarding theory on leadership and competency, principals have exhibited knowledge of administration and leadership but their perceptions did not show logical and systematic understanding as set out in the Distributed Leadership Framework. Leadership training is needed to help them understand leadership theory.

2 The participants' high self-evaluation about their own leadership demonstrates their inferior confidence in their own position and abilities. The deficiencies in leadership competencies identified by themselves -- such as education theory, study and research ability, communication skills, and creativity - demonstrate the need for training workshops focused on skill, knowledge, and attitudes.

3 From the key staff structure, gender imbalance is apparent. All instructional leadership positions of the sample schools of this research are $100 \%$ held by males only. Female principals are also reported by the interviewees that they do not have confidence in their leadership. Based on extensive research results, in an educational organization, gender balance is important. A female principal not only benefits the educational organization itself, but also encourages female staff, especially female students, by setting a good example. Amhara region and/or the federal ministry of education should learn from developed countries like Canada and build up supporting systems to encourage and train more and confident female principals. South Gondar Administrative Zone principals appreciate the theory underlying the distributed Principal Leadership Framework, especially that the leadership of an active principal is essential in improving student achievement. However, in reality, South Gondar Administrative zone principals complain that the recruitment procedure of principals has distorted the nature of education and restricted principals' capacity to enhance quality. As well, excessive outside interference has adversely influenced normal educational sequences and too much external coordination wastes a principal's time and energy. All such factors result in less attention to student achievement and all-round development.

4 How to play an effective role in student achievement is not just a principal's duty but is a system issue that demands the supports of the whole society -- including governments at federal, regional and woreda level, schools, parents and community.

5 The professionalization of the principal position in the region or in the country does not impress many participants. Setting up a professionalized standard such as the national Professional Standard for School Principals, Continuous Professional Development Programme and strengthening related training might be an effective way to improve educational leadership in the administrative zone or in the region.

\section{REFERENCES}

Campbell, R. (1987). A history of thoughts and practical educational administration. New York: Teachers College Press.

Catano, N., \& Stronge, J. H. (2007). “What do we expect of school principals? Congruence between principal evaluation and performance standards". International Journal of Leadership in Education, 10, 379-399.

Cuban, L. (1984). Transforming the frog into a prince: Effective schools research, policy, and practice at the district level. Harvard Educational Review, 54, 129-152.

Cunningham, W., G. and Paula A. C.(2009). Educational leadership: A bridge to improved practice (4th ed.). Boston: Pearson education, Inc. 
Asian Journal of Humanity, Art and Literature, Volume 1, No 1 (2014)

Damtew, T. (2007). Building research capacity in Ethiopian universities: The realities andthe challenges. Speech on United Nations Economic Commission for Africa (UNECA). Retrieved from: http://www2.bc.edu/\%7Eteferra/Building_Research_Capacity_in_Ethiopia.html

Darling-Hammond, L. (2005). Developing professional development schools: Early lessons, challenge, and promise. In L. Darling-Hammond (Ed.), Professional development schools Schools for developing a profession (pp. 1-27). New York: Teachers College Press.

Endawke, et. al. (2009). Quality of Higher Education in Ethiopian Public Institutions. Forum for Social Studies. Addis Abeba University Press.

Fullan, M. (2006). Leading professional learning. The School Administrator, 63(10), 10-15.

Goodwin, R. H., Cunningham, M. L., \& Childress, R. (2003). The changing role of the secondary principal. NASSP Bulletin, 87(634), 26.

Hallinger, P. (2003). "Leading educational change: Reflections on the practice of instructional and transformational leadership". Cambridge Journal of Education, 33(3), 329-351.

Hallinger, P. (2008, March). "Methodologies for studying school leadership: A review of 25 years of research using the principal instructional management rating scale". Paper presented at the annual meeting of the American Educational Research Association, New York.

Halverson, R. (2005). Education Leadership and Policy Analysis.Washington, D.C. : University of Wisconsin-Madison.

Hammersley, M. (2012). Methodological Paradigms in Educational Research, British Educational Research Association on-line resource.

Kiumi, J., Bosire, J. and Sang, A. (2009). “Relationship between principals' management approaches and student discipline in public secondary schools in Nyandarua and laikipia Districts, Kenya". Global Journal of Educational Research Vol. 8(1\&2) 2009, p.29- 38.

Leithwood, K. (2012). "School leadership, evidence-based decision making, and large-scale student assessment". Studies in Educational Leadership, 15, 17-39.

Leithwood, K., Patten, S., \& Jantzi, D. (2010). “Testing a conception of how school leadership influences student learning". Educational Administration Quarterly, 46, 671.

Leithwood, K., Seashore Louis, K., Anderson, S., and Wahlstrom, K. (2004). How leadership influences student learning. Bloomington: Center for Applied Research and Educational Improvement. University of Minnesota.

Lemlem, T. (2010). "Review of some recent literature: Identifying Factors that Affect Ethiopia's Education Crisis", Ee-JRIF Vol 2, No 22010 - Education Issue: pp. 56-68.

Levine, A. (2005). Educating school leaders. New York: The Education School Project.

Lyne de Ver, H. (2009). "Leadership, Politics and Development: A Literature Survey", LECRP Background Paper, http://www.dlprog.org

MOE. (2010) Education Sector Development program: Action plan, Addis Ababa: printing press.

MOE. (2012) National Standard for School Principals (First edition MoE: Ethiopia) Page 3

Northouse, P. G. (2007). Leadership: Theory and practice (4th ed.). Thousand Oaks, CA: Sage.

Onderi, H. and Andrew, M. (2013). "Secondary School Principals in Nyamira County in Kenya: Issues And Challenges, Bondo University College: KENYA", Reading Gap International CIC, UK. Vol. 1 No. 1,

Pankhurst, R. (1999). “Italian Fascist War Crimes in Ethiopia: A History of Their Discussion, from the League of Nations to the United Nations" (1936-1949) Northeast African Studies Vol. 6, No. 1-2 (New Series), pp. 83-140.

Stronge, J. H. (1993). “Defining the principalship: Instructional leader or middle manager". NASSP Bulletin, 77(553), 1-7.

Tekeste N. (2006). Education in Ethiopia: From crisis to the brink of collapse. Nordiska Afrikainstitutet 33. Uppsala, Sweden: Nordiska Afrikainstitute.

Tyack, D. B., \& Hansot, E. (1982). Managers of virtue: Public school leadership in America, 1820-1980. New York: Basic Books.

World Bank. (2005) Education in Ethiopia: Strengthening the foundation for sustainable progress. Washington, DC: The World Bank.

Yukl (2002). Leadership in organizations. (5th ed.). Upper Saddle River, New Jersey: Prentice Hall. 


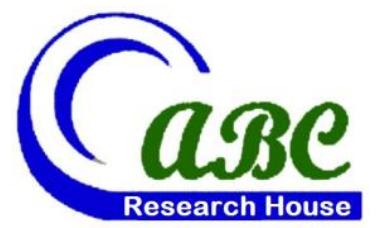

- Off Pantai Dalam, Kuala Lampur, Malaysia

- Road \# 4, Shyamoli, Dhaka-1207, Bangladesh

- 3900 Woodhue Place, Alexandria, VA 22309, USA

www.abcreorg.weebly.com / www.abcjournals.net

Asian Business Consortium (ABC) is a multi-disciplinary research, training, publishing, digital library supporting and service house. Though founded in 2010 as the Business and Computing organization of Asia, it was reconstituted as the ABC in 2011. It has been working for creating and nurturing talents in USA, Malaysia and Bangladesh since its inception. The objectives of consortium are solely centered round the welfare and humane attitude of the founders who enthusiastically took up this noble cause and materialized it with a view to promote research and educational activities for the encouragement of scholars to develop their knowledge, to publish their analysis oriented scientific researches in international Journals, books, the task of organizing workshops, seminars, conferences, training, personality development programs and allied services.

In addition to research activities, $A B C$ provides a good number of scholarships to the poor and meritorious students at various levels of education throughout the world. It plays an important role in the field of research by funding research projects and publishing the research papers. This consortium will unquestionably become the mouth-piece of the dark horses and unacknowledged scholar whose endowed and commendable contributions shall be provided an outlet keeping in mind the greater good of the larger society of the world.

$\mathrm{ABC}$ runs the following international referred journals for creating a platform to share the thoughts of professionals, scholars and academicians throughout the world.

\section{ABC Publications (ABC Journals)}

- Asian Accounting and Auditing Advancement (4A Journal)

- Asian Business Review (ABR)

- Asian Journal of Applied Sciences and Engineering (AJASE)

- Global Disclosure of Economics and Business (GDEB)

- $\quad$ ABC Journal of Advanced Research (ABC-JAR)

- International Journal of Reciprocal Symmetry and Theoretical Physics (IJRSTP)

- American Journal of Trade and Policy (AJTP)

- Asian Journal of Humanity, Art and Literature (AJHAL)

- Malaysian Journal of Medical and Biological Research (MJMBR)

- $\quad$ Asia Pacific Journal of Energy and Environment (APJEE)

- $\quad$ Engineering International (EI)

- $\quad$ ABC Research Alert (Online)

Each journal home page provides specific information for potential authors and subscribers. Open access policy, the quick review process, rich editorial boards and quality publications have already made $A B C$ Journals unique. ABC Journals are published under the direct supervisions of renowned academicians of the world.

Collaboration in Conference: $\mathrm{ABC}$ considers high-quality conference papers for publication. Please contact us for detailed information.

Collaboration in Publishing: If you like to start writing a book, propose a new journal or advertise in $\mathrm{ABC}$ journals, please feel free to contact us. 